Macroeconomics at the crossroads: Stagflation and the struggle between "Keynesian" and New Classical macroeconometric programs Aurélien Goutsmedt ${ }^{\mathrm{a} *}$

${ }^{a}$ Université Paris I Panthéon-Sorbonne, Centre d'Economie de la Sorbonne. Fellow at Duke University, Center for the History of Political Economy. E-mail address:

ag493@duke.edu 


\title{
Macroeconomics at the crossroads: Stagflation and the struggle between "Keynesian" and New Classical macroeconometric programs
}

\author{
Lucas and Sargent's “After Keynesian Macroeconomics" is considered as a \\ cornerstone of macroeconomics history and is supposed to have seriously \\ undermined "Keynesian" approach to macroeconometric modelling. I study the \\ context of this article, its writing, its presentation in a conference with many \\ advocates of large-scale models and the debates that followed. I demonstrate that \\ the issue of stagflation was closely linked to Lucas and Sargent's argument, and \\ the opposition of "Keynesians" relied on their different interpretation of \\ stagflation. I show this interpretation of stagflation led to a different research \\ program, which has been overlooked by history of macroeconomics.
}

Keywords: History of macroeconomics, Keynesian economics, Microfoundations, Structural Macroeconometric Models.

JEL codes: B22, B41, E60

\section{Introduction}

How to explain the significant transformations of macroeconomics after the 1970s? The issue continues to interrogate historians of macroeconomics as well as macroeconomists. During Summer 2014, Paul Krugman (2014) and Simon Wren-Lewis (2014a, 2014b) disputed the correct interpretation of the "New Classical Revolution" in their respective blogs. Wren-Lewis thought that the "New Classical revolution" remained methodological above all. It came from economists "unhappy with the gulf between the methodology used in much of microeconomics, and the methodology of macroeconomics at the time" (Wren-Lewis 2014a). On the opposite side, Krugman (2014) argued that the stagflation did play a decisive role in boosting the success of the New Classical analysis. Economists, as people outside academia, regarded Friedman (1968) as anticipating the simultaneous rise of unemployment and inflation.

Consequently, this provided some empirical ground to the natural rate hypothesis, 
which consequently favoured the reception of Robert Lucas and Thomas Sargent's work on microfoundations. However, Wren-Lewis explained that Keynesians quickly demonstrated their ability to explain the stagflation with an "accelerationist Phillips curve" in addition to the idea that policymakers underestimated the natural rate of unemployment. If, despite their prompt reaction to adapt their models and explain stagflation, Keynesians were relegated into the background, this proves (although indirectly) that stagflation was not that decisive in the transformation of macroeconomics. He concluded that the "fatal flaw" of the Keynesian theory in the 1970s was "theoretical rather than empirical" (Wren-Lewis 2014a).

In a second blog post titled "Re-reading Lucas and Sargent 1979", Wren-Lewis (2014b) focused on the "After Keynesian Macroeconomics" article by Lucas and Sargent (1978). ${ }^{1}$ Regarding it as the "manifesto" of the new classical school, he claimed: "it deserves to be cited as a classic, both for quality of ideas and the persuasiveness of the writing". He argued that such a re-reading shows that the methodological part lay at the heart of the article and that Lucas and Sargent did not link their criticism of "Keynesian" macroeconometric models to stagflation.

Consequently, "it was this methodological critique, rather than any superior empirical ability, that led to the success of this manifesto".

My goal in this article is not to arbitrate Krugman and Wren-Lewis's opposition. It is rather to enlighten our understanding of the issue by analysing deeper the context of Lucas and Sargent's “After Keynesian Macroeconomics". They presented their attack

${ }^{1}$ The year 1979 refers to the reprint in the Quarterly Review of the Federal Reserve Bank of Minneapolis. However, the article was originally published in 1978 in the proceedings of the conference where Lucas and Sargent presented it. 
against "Keynesian" macroeconometric models during a conference organised by the Federal Reserve Bank (FRB) of Boston, and titled "After the Phillips Curve: the Persistence of High Inflation and High Unemployment" (FRBB 1978). ${ }^{2}$ As the FRB of Boston appeared somewhat close to the Keynesian's positions, most of the speakers were in league with the practices Lucas and Sargent dismissed. Thus, the conference witnessed a confrontation between the two factions. More generally, it will appear that 1978 represented a crucial year: the New Classical ideas seemed to gain in influence, while many macroeconomists continued to defend with fervour the use of Keynesian macroeconometric models.

This article raises two critical points that have been scarcely tackled by historians. First, I assess the importance of stagflation in this debate. Part of works in macroeconomics history overlooks any effect of the economic context on the transformations of macroeconomics in the 1970s. Others regard it as a fundamental impulse, which helped the changes, but without detailing the mechanisms or explaining in which context stagflation turned out to be important. ${ }^{3}$ This article shows that you

${ }^{2}$ By using the term “Keynesian”, I am following Lucas and Sargent's usage. However, it is far from being an accurate description of this type of models as they integrated many features that were not Keynesian per se. Besides, Klein, for instance, seemed reluctant to use this label and defended what he called the "Leontief-Keynes system" (Klein 1978) or the "Keynes-Leontief" model (Klein 1982). In this article, even if I will use the label "Keynesian macroeconometric model" in reference to Lucas and Sargent, I would prefer the expression "large-scale macroeconometric model", which seems more neutral to describe the models Lucas and Sargent targeted: "The Wharton model, the Michigan model, the MPS model" (Lucas in Snowdon and Vane 1999, 155).

${ }^{3}$ Gregory Mankiw (1990, 1648), for instance, claimed that if the stagflation had never occurred, or if the macroeconometric models would have explained the events easily, the New Classical ideas would have never gained popularity. Lucas himself acknowledged some "luck" in the timing of their works (see the interview in Klamer [1984, 57]). As for 
cannot disentangle the issue of stagflation from the methodological controversy that was running on in the late 1970s. Admittedly, Lucas and Sargent built a general case to criticise Keynesian modelling, and their point is logically independent of the economic situation of the time. Nevertheless, at the same time, the initial motivation to raise this point followed the forecast errors encountered by large-scale macroeconometric models in the early 1970s. This implied that economists confronted their views about where these errors came from. This article demonstrates that to each methodological program - the New Classical one, and what I call the "aggregation program", following Hoover (2012) — corresponds a particular explanation of stagflation. In other words, the more one tends to defend a particular explanation of stagflation, the more one tends to advocate for a particular methodology of macroeconometric modelling.

Second, this first point allows me to highlight the persistence of a competitive research program to the New Classical methodological framework, the "aggregation program”. Despite facing New Classical criticisms, this program appeared as still "progressive" in the Lakatosian meaning, still legitimate in many institutions (public or private) and it endeavoured to account for the stagflation. ${ }^{4}$ This article refines the

historians, focusing on analytical and methodological issues of the New Classical turn in macroeconomics, Kevin Hoover (1988) and Michel De Vroey (2016) rarely mention stagflation. De Vroey underlined that some economists saw it as a "real-world confirmation of Friedman's theory" (108) and explained that with "stagflation methodological criticisms, and the ascent of an alternative approach", the "[Keynesian] consensus broke down" (169). However, De Vroey did not study how macroeconomists debate explaining the stagflation, or how their interpretation of the events shaped the way they discuss macroeconomic methodology.

${ }^{4}$ At that time New Classical economists had not yet developed any empirical macroeconometric model following their methodological instructions. This was partly fulfilled by Finn Kydland and Edward Prescott 1982). 
understanding of what opposed the two programs. It did not appear as an issue of being for or against microfoundations, but instead of the types of microfoundations to favour. ${ }^{5}$ The two programs expressed different views on the relation between economic theory and econometric modelling, as well as on what should lead the improvements of the models. Whereas the defenders of the aggregation program remained omnipresent in conferences in the late 1970s, and despite the continuous evolution of their models during the period, few publications tackled the persistence of these applied works. ${ }^{6}$ Recent articles by historians studied the elaboration of macroeconometric models in the 1960s (Acosta et Cherrier 2018; Acosta et Pinzón-Fuchs, forthcoming; Cherrier et Backhouse 2018), but nothing has been written yet on the survival of these practices during the 1970s. Consequently, this article is a first step to understand how the advocates of large-scale macroeconometric models defended their practice against New Classical economists in the context of stagflation and envisaged the future of these models. It prevents to believe a simplistic standard narrative overestimating the transformations of the discipline at the time and regarding the New Classical offensive against "Keynesian" economics as totally successful. ${ }^{7}$

\footnotetext{
${ }^{5}$ This issue remains far from obvious today. For instance, Shimer $(2009,280)$ explained that what distinguishes "modern macroeconomics" is that "models build upon two foundations": "First, households maximize expected utility subject to a budget constraint. Second, firms maximize expected profits". However, large-scale models in the 1970s relied on the same foundations (see below).

${ }^{6}$ Snowdon and Vane (2005) did not direct their attention towards macroeconometric building. They did not evoke what happened after the Klein-Goldberger model (1955). Similarly, De Vroey (2016) did not mention the transformations of macroeconometric modelling after the 1960s.

${ }^{7}$ A good example is Robert Hall $(1996,38)$ claiming: "The Lucas critique . . . has revolutionized the evaluation of policy, down to the most practical level in central banks
} 
I relate first the controversy occurring around Lucas and Sargent's presentation during the conference. I then move to describe the two different kinds of explanation for stagflation that Lucas and Sargent from one side and advocates of the aggregation program from the other side defended. I show how these explanations led economists to plead for different transformations of macroeconometric modelling. Third, relying mainly on Klein's numerous writings on large-scale models in the late 1970s, I describe the features of the aggregation program and how macroeconomists involved in it endeavoured to improve the models in front of the unprecedented economic situation. It offers a better picture of the confrontation between the two camps, even if it also underlines how poor the mutual understanding was and how few the lines of convergence seemed.

\section{The Martha's Vineyard Controversy}

The $1^{\text {st }}$ and $2^{\text {nd }}$ of June 1978 , the FRB of Boston gathered famous macroeconomists to discuss modelling and stagflation in Martha's Vineyard—an island south from Boston. At that time, among the twelve federal reserve banks, the FRB of Boston seemed one of the most interventionist and most reluctant to accept disinflation policies. ${ }^{8}$ The proximity of the MIT could, of course, explain a lot of it. Robert Solow sited as a

and finance ministries.... Work on the Phillips Curve has been virtually abandoned, devastated by the theoretical and empirical force of the critique". Besides the situation being much more complicated than what Hall describe in 1996, the process of change in macroeconomics - and about the Phillips curve more particularly — were not as simple and straight.

${ }^{8}$ See the record of Meltzer (2010, chapter 7) on the positions of the FOMC during the early 1970s, or Chappell et al. (2005). 
member of the FRB Board of governors at the time, and Franco Modigliani regularly attended the "Academic Consultant Meetings".

Lucas and Sargent knew where they were getting into and wanted to exploit the situation:

We were invited to a conference sponsored by the Boston Fed. In a way, it was like being in the enemy camp and we were trying to make a statement that we weren't going to be assimilated. (Lucas in Snowdon et Vane [1998, 128])

Besides professors and associate professors working in universities (like Martin Baily, Benjamin Friedman, Klein, Lucas, Modigliani, William Poole, Sargent or Solow), economists working for public institutions or Federal Reserve banks attended (Stephen McNees and Frank Morris for the FRB of Boston, Edwin Truman for the Board of Governors, Sally Ronk for the Treasury, or David Wyss for the Council of Economic Advisors), as well as journalists (from the Boston Globe, the Wall Street Journal, Business Week and the Washington Post) and civil society representatives (Napoleon Johnson II from the National Urban League, or Barbara Becknel from the AFL-CIO). ${ }^{9}$ Introducing the conference, Frank E. Morris $(1978,9)$, the President of the FRB of Boston, justified the composition of such an eclectic meeting: the conference aims at generating "one building block or two upon which a new synthesis will be based" in order to inform economic policy as efficiently as in the 1960s.

Manifestly, Lucas did not like this mix between serious research issues and policy-oriented discussions. In a letter addressed to Sargent a month after the conference, he expressed his grievance against the general philosophy of the meeting:

\footnotetext{
${ }^{9}$ See "Conference Participants" (FRBB 1978, 216-17).
} 
I think this is why Martha's Vineyard was so unsatisfactory: the ostensible function was to discuss scientific issues, but the format was arranged with journalistic and policy ends in view. We had to pretend to be talking economics for Lindlay Clark's [sic] benefit, but we had to be sure not to pretend too well, or he wouldn't be able to follow what was going on. ${ }^{10}$ (RLP 3, Folder "1978 4/4", 21/07/1978)

Nevertheless, before the conference, Lucas did not seem totally opposed to the idea of spreading their ideas across a non-only academic public. ${ }^{11}$ According to Morris's letter of invitation, it seems first that Lucas and Sargent agreed with Robert Eisenmenger (Vice-President of the FRB of Boston) on a discussion about "the persistence of high inflation and high unemployment from a rational expectations point of view" and on "an empirical examination of these issues" (RLP19, Folder "After Keynesian Macroeconomics (1978-1979) 1", 22/11/1977). However, this perspective disappeared in Lucas and Sargent's mind at least as soon as February 1978. According to Lucas, both "agreed on a frankly rhetorical piece as opposed to the presentation of new scientific results", with the goal "to convey to a wider audience some of what we think we know, and to convince others that the old-fashioned macro game is up" $(9 / 02 / 1978)$. A recurrent discussion between Lucas and Sargent bore upon the title of their contribution. Lucas first thought was "Remaking Aggregative Economics" but he regarded it as "over-dramatic" (RLP3, Folder "1978 1/4", 9/05/1978), and they moved to a more neutral "Some Recent Development in Aggregative Economics" (RLP19, “After Keynesian Macroeconomics (1978-1979) 2"). Interestingly, they finally chose a

\footnotetext{
${ }^{10}$ Lindley Clark was an influential associate editor of the Wall Street Journal.

${ }^{11}$ As Goutsmedt, Guizzo and Sergi (2019) pointed out, this ambivalent attitude towards engaging with the public debate was typical of Lucas.
} 
more "dramatic" title, which fit better the aggressive tone of their presentation. ${ }^{12}$

After a first part of the meeting aiming at "documenting the problem", the second part on "New Explanations of the Persistence of Inflation and Unemployment was introduced by the presentation of Lucas and Sargent. ${ }^{13}$ Their article is well-known, and De Vroey (2016, chapter 12) offers a summary and discusses B. Friedman's answer. Consequently, I will tie myself to remind the essential arguments of the article, even if I will linger over the interpretations and reactions to their presentation.

Lucas and Sargent criticised the choice of the restrictions put on large-scale macroeconometric models. These restrictions did not rely on the proper theory, that is the standard microeconomic theory with optimising agents in the spirit of Arrow and Debreu's model (1954). The problem the models lied in the lack of "foundations in microeconomic and general equilibrium theory" (Lucas and Sargent 1978, 54). ${ }^{14}$ Indeed, according to them, the deductions of microeconomic theory generally contradicted the restrictions imposed on behavioural equations by Keynesian macroeconometric models. The adaptive expectation assumption constituted a perfect example as they regarded it as going against individual rationality because it does not follow any microeconomic optimisation principle. They also criticised the restrictions on error terms that imply the absence of cross-equation serial correlation. Thirdly, they rejected the choice of exogenous and endogenous variables.

${ }^{12}$ It is worth noting that the archival evidence enables to observe that the final published version remained pretty close to the draft they had wrote before the conference.

${ }^{13}$ Other significant presentations in this second part were Klein (1978a) on the LINK model, a global multi-country model, and Fair (1978) presenting his own large-scale model of the U.S.

${ }^{14}$ They also mentioned the modern probabilistic theory and quoted Debreu (1959) and Arrow (1964). 
Given these three arguments, they claimed that no reason existed for the behavioural parameters of the model equations to be truly structural, which undermined the models ability to evaluate economic policies. Two empirical arguments supported their claim. First, Muench, Rolnick and Wallace's (1974) article demonstrated the instability of the behavioural parameters of the FRB-MIT model across different samples. Second, they invoked the economic situation in the 1970s as a "decisive test" (Lucas and Sargent 1978, 56).

Lucas and Sargent remained cautious on this second point. They did not blame directly Keynesian economists for the "erratic" stabilisation policies of the 1970s. Nevertheless, they argued that Keynesian models predicted that the outcome of these policies would have been "the lowest average unemployment rates for any decade since the 1940s", and instead we observed "the highest unemployment since the 1930s" (57), what allegedly testified of parameters' instability. They concluded polemically: "this was econometric failure on a grand scale". They regard the Keynesian program as a dead end:

\footnotetext{
Some, of course, continue to believe (...) that these models can be adequately refined by changing a few structural equations, by adding or subtracting a few variables here and there, or perhaps by disaggregating various blocks of equations. We have couched our preceding criticisms in such general terms precisely to emphasize their generic character and hence the futility of pursuing minor variations within this general framework. (57)
}

Followed a defence of their general equilibrium approach to business cycles, which they regarded as an answer to the fundamental problems of Keynesian macroeconometric models and as the basis for building future models. Their approach combined the postulates that markets clear and agents pursue their self-interest (that is "agents optimize" [60]), with the imperfect information hypothesis. 
As a discussant of their article, B. Friedman disagreed with the sharp divide they introduced between the Keynesian macroeconometric approach and the general equilibrium one. First, he contradicted the distinction on the microfoundations line, claiming that optimising agents existed in current models and this remained a primary concern in this framework. ${ }^{15}$ Friedman cited Fair's model (1978), presented in the conference, with agents maximising inter-temporally profit and utility functions. On the issue of arbitrary restrictions, while acknowledging weaknesses in existing models, he targeted Lucas's and Sargent's models for which one can spot such "ad hoc" restrictions (Lucas and Sargent 1978, 76-77). ${ }^{16}$ Friedman lastly pointed out the striking turn of phrase of the authors and confessed he thought "a lower rhetorical profile would better advance the cause of scientific interchange" (80).

In his discussion of Fair's article, Modigliani also tended to minimise the general claim of Lucas and Sargent. He "[trusted] that in the final version of their paper [they] will choose to stress that their analysis of rational expectations is not to be seen as a radical break" but rather as a "stimulating contribution to an area which has long been recognized as deficient (...) - namely that of modeling expectations" (Fair 1978, 194).

${ }^{15}$ After the conference, Lucas and Sargent added a supplementary footnote to the revised version - and it was the only major revision — to acknowledge that it exist many works in the spirit of "optimizing microeconomic theory" by economists within the Keynesian tradition" $(1978,54)$. Nevertheless, they claimed that "it has become increasingly apparent that microeconomic theory has very damaging implications for the restrictions conventionally used to identify Keynesian macroeconometric models"- yet they brought no precise reference to their claim.

${ }^{16}$ He gave two examples: a theoretical one, targeting the structure of Lucas's (1972) imperfect information model and an empirical one, criticizing the estimation strategy of Barro (1977) on the effect of unanticipated monetary policy. 
In the conclusion of the conference, Solow $(1978,204)$ also charged Lucas and Sargent for their vocabulary that he found exaggerated. ${ }^{17}$ He followed Modigliani's point and considered that "the very strong language" he read "simply doesn't square with what in fact actually happened" (204). Ironically, he gave a "B and some a B minus on occasion" to "standard models", and for him nothing in "that record (...) suggests suicide".

The conference witnesses how macroeconomics was at crossroads in 1978 and the gap seemed pretty wide between the advocates of large-scale models and New Classical economists. Each group hardly listened and discussed the arguments of the other. Lucas wrote to Sargent after the conference and appeared disappointed: "the conference was a real depressant. It will take a while for me to figure out the sense in which such occasions are 'good for us"” (RLP3, Folder "1978 4/4", 19/06/1978). He thought Friedman did not answer to "any of the substantive contentions in the paper!" and thus regarded a brief reply as necessary. He nonetheless believed they should not modify their article and, above all, that nothing was "overstated" in it. He added: "by the standard Solow set on both days, I think we were rather subdued." In his response, Sargent agreed not to revise the article too much. He confessed that people at the FRB of Minneapolis "were very surprised when I told them that our paper was characterized as "polemical"” as well as when he "summarized some of Solow's comments" (RLP19, Folder “After Keynesian Macroeconomics (1978-1979) 1”, 28/06/1978). ${ }^{18}$

${ }^{17}$ Solow $(1978,204)$ made an inventory of all the expressions used by the authors: "“widely incorrect,' 'fundamentally flawed,' 'wreckage,' 'failure,' 'fatal,' 'of no value,' 'dire implications,' 'failure on a grand scale', 'spectacular recent failure,' 'no hope'.'.

${ }^{18}$ Solow's role in this lack of productive communication appeared important. Paul Romer (2015) who began his Ph.D. at MIT at the end of the 1970s, before to move to Chicago, considers that Solow contributed to enlarge the gap between the two groups by being 
In their rebuttal, Lucas and Sargent $(1978,81)$ argued that Friedman "[made] no effort to explain either how [his] proposition is related to anything in [their] paper (it is not) or what possible bearing it might have on the questions of economic policy which [they] thought were under discussion". Friedman, who was also allowed to write a rejoinder in the proceedings, blamed their lack of answer to the questions "do not the MPS and other current 'Keynesian models' include these optimizing features? Is the intended contrast against today's models or against those of a generation ago? Why not say precisely which models are under criticism and then look carefully at their actual record of performance" (83). No convergence could be hope after such contradictory claims. Even worst, no agreement on where the disagreements lied appeared.

In the two next sections, I will analyse two crucial elements of the debate that contribute to explaining the reasons behind such a lack of mutual understanding.

\section{A spectre haunting the conference: the stagflation}

Two types of explanation for stagflation emerged from the conference. The first one insists on the role played by economic agents' adaptation to a changing economic

"sarcastic" and by refusing any "serious engagement". We can also suppose that Solow progressively became tired of New Classical arguments and rhetoric. In 1973, he conceded a "very favorable" general impression on Lucas. Despite Lucas's "very strong and narrow convictions about very simple and narrow principles", "he is ingenious enough so that he makes something interesting of them" (RSP5, Folder "September-October 1973", 17/10/1973). The tone brutally changed after the conference: asked to rank a large set of macroeconomists for tenure appointments, he assessed the New Classical economists separately. He ranked Lucas before Robert Barro and Sargent, but claimed: "They're all mad so far as I'm concerned” (RSP 10, Folder “January-February 1979”, 10/01/1979). 
environment. Lucas and Sargent implicitly targeted the policies of the 1960s and early 1970s that were too expansionary and thus created a more inflationary environment. The opposite camp underlined the role played by external factors: the end of Bretton Woods, the bad harvests, and the 1973 oil shock. The two last elements constitute supply shocks that increase prices and reduce production.

\subsection{The New Classical Explanation}

Lucas and Sargent did not focus their argumentation on stagflation. Nevertheless, one can easily understand through some passages in their article which kind of explanation they favoured. They designated their target from the very first line, assimilating, although with some vagueness, the failure of economic policies since the end of the 1970s and the wrong predictions of the "Keynesian doctrine":

We dwell on these halcyon days of Keynesian economics because, without conscious effort, they are difficult to recall today. In the present decade, the U.S. economy has undergone its first major depression since the 1930s, to the accompaniment of inflation rates in excess of 10 percent per annum. These events have been transmitted (by consent of the governments involved) to other advanced countries and in many cases have been amplified. (Lucas and Sargent 1978, 49)

They continued by highlighting that this economic situation followed expansionary policies defended by the Keynesian framework:

These events did not arise from a reactionary reversion to outmoded, "classical" principles of tight money and balance budgets. On the contrary, they were accompanied by massive governmental budget deficits and high rates of monetary expansion: policies which, although bearing an admitted risk of inflation, promised according to modern Keynesian doctrine rapid real growth and low rates of unemployment. That these predictions were wildly incorrect, and that the doctrine on which they were based is fundamentally flawed, are now simple matters of fact, involving no novelties in economic theory. (Lucas and Sargent 1978, 49) 
Further in the article, when discussing the issue of invariance of parameters, they claimed that Keynesian models predicted that the 1970s economic policies would reduce unemployment to a very low level. The eventual increase in unemployment proved for the authors that the relation between inflation and unemployment had changed because of the policies. Nevertheless, they never stated the case explicitly in the article. ${ }^{19}$

In their answer to Benjamin Friedman's discussion, Lucas and Sargent (1978, 82) pointed out that their empirical attack concerned a "specific and well-documented event", the year 1970. Econometric models predicted a relatively low rate of inflation for a 4 per cent rate of unemployment, and the modellers placed the result "at the center of a policy recommendation to the effect that such an expansionary policy be deliberately pursued". ${ }^{20}$

In the conclusion of the conference, Poole actually made the point more explicit. He questioned ironically the title of the conference, claiming that we should have replaced "After" by "Because of" the Phillips curve, for the reason that "belief in a stable tradeoff between inflation and unemployment has had much to do with the persistence of excessively expansionary policies since 1965" (Poole 1978, 210). This explanation presaged what will be later called the "idea hypothesis" after Christina

${ }^{19}$ Many more indications can be found in Sargent's work, who dealt in the early 1980s with the Thatcher's and Reagan's policies and the ways to reduce inflation (Sargent 2013; Goutsmedt 2018).

${ }^{20}$ Lucas and Sargent's precision is confusing here. If they are targeting the models prediction in 1970, the consequences of the policies they are mentioning in the article introduction (the "first major depression since the 1930s" and "inflation rates in excess of 10 percent per annum") referred to the year 1974, namely after Bretton Woods collapse and the 1973 oil shock that could hardly have been forecasted in 1970 by the large-scale models. 
Romer (2005). This stance defends the view that "economic ideas were the key source of the Great Inflation" (177). The wrong economic idea was the belief in a long run trade-off between inflation and unemployment. Thus, stagflation resulted from faulty economic policies, led by policymakers who thought they could permanently lower unemployment by stimulating aggregate demand, a policy which pushed inflation lastingly higher because of individuals' expectations adjustment. ${ }^{21}$

Even if Lucas and Sargent did not offer any detailed or at least explicit explanation of the stagflation, it remains that the issue appears crucial in their argumentation. Answering to Herschel Grossman comments on their article, Lucas argued:

The importance of the erroneously forecast tradeoff (which is what we mean by "failure of a grand scale") is that it permanently altered the climate in which we practice our trade. (...) Tom and I spent a good part of our paper on exactly this question: is this error attributable to some correctable feature of the standard macroeconometric framework, or is it a symptom of some more basic difficulties? This issue is arguable among honest people, so we argued it, concluding that the letter conclusion is correct. (RLP3, Folder "1978 3/4", 21/07/1978)

In terms of logic, Lucas and Sargent's point did not need the stagflation: it was a general argument about the way models were built. However, their point of departure to support the legitimacy of their claim relied on the forecast errors of the early 1970s. Consequently, it linked de facto the issue with the interpretation of these errors. It

${ }^{21}$ The idea hypothesis seems the dominant explanation today even if still debated. In a 2008 NBER conference on the "Great Inflation" of the 1970s, DiCecio and Nelson (2013), Goodfriend and King (2013), and Levin and Taylor (2013) explained the inflation of the 1970s by policy mistakes and misguided belief in a stable Phillips curve, whereas Blinder and Rudd (2013) supported a supply-shock-led explanation. 
implied to wonder where they come from and so how to correct it. If Lucas and Sargent proposed a supposed radical break with previous practices, it had to do with their own interpretation of the causes of these errors, and so of the stagflation. However, this also opened the door for other interpretations.

\subsection{The external factors as the ideal culprits}

Many economists attending the conference seemed to consider that the rise in inflation and unemployment had to be explained primarily by the role played by external factors like the end of Bretton Woods, the bad crops or the OPEC shock. Klein (1978a) underlined that the major feature of the macroeconomic situation remained the number of disturbances hitting the U.S. and the global economy. ${ }^{22}$ With the LINK project, he aimed at endogenising export volumes and imports prices in the model to study the international transmission mechanisms and the spillover effects of economic policies. ${ }^{23}$ He targeted a better understanding of inflation transmission between countries, and so of the role of trade, exchange rates and national policies in stagflation.

In his article, Klein studied the effects of an increase in basic commodity prices. He ran an indirect test by showing what would have prevailed if the embargo and the oil price shock had not taken place. He exposed "how important energy is in the pricing

${ }^{22}$ Klein's list was large, going from the "Nixon shocks", the end of Bretton Woods, the Soviet new purchases impact, the oil embargo, to the increase both in protectionism and capital transfers, the wage offensive of Unions, and also the international debt defaults and the speculation on currencies and commodities. (Klein 1978a, 84).

${ }^{23}$ For more information on the development of the LINK model, see Hickman (1991). The project was launched by the Committee on Economic Stability and Growth of the Social Science Research Council, which wanted to study more carefully international transmission mechanisms. It created a system to connect several national models. 
decision" (Klein 1978a, 95) but also its impact on production. The results showed how inflationary impulses from energy prices generated more inflation and rising unemployment (99). He added that because of the role of petroleum in the process of production, an embargo could damage output, due to bottlenecks and slow production substitutions, what eventually led to an increase in unemployment (102).

John Helliwell, Professor of Economics at the University of British Columbia, discussed Klein's article. He proposed numerous additional elements enabling the model to capture more precisely some crucial features like capital flows. However, he claimed that these extensions would not change the basic conclusion-and would instead be likely to strengthen it — that "the oil price increase have been an important source of the mid-1970s stagflation in the industrial economies" (Klein 1978a, 115). Helliwell yet conceded that economists still lacked an assessment of "the relative importance of monetary and nonmonetary causes of the world inflation of the 1970s, or about the origins of the increases in the prices of oil and other major commodities". In other words, it did not allow rejecting the Monetarist and New Classical explanations.

In his presentation, Fair (1978) proposed the same kind of analysis than Klein, but with a "disequilibrium model". The model was microfounded with clearly identified optimisation problems (consumers maximising their utility and firms and banks maximising their profits), but with external constraints on the process of optimisation, like credit or hours worked constraints. ${ }^{24}$ His model led him to conclude that demand pressure had only a low impact on prices and wage inflation in the 1970s. However, a significant source of inflation in the model was the price of imports (182). He then ran

\footnotetext{
${ }^{24}$ Fair was one of the pioneers of developing econometric tools for disequilibrium models (Fair and Jaffee 1972).
} 
simulations with a slightly lower federal fund rate for the period 1971I-1975I and concluded that "the unemployment rate by the end of the period would have been 1,9 percentage points lower than it actually was (...). Inflation, on the other hand, would have been little changed" (184).

Concluding his discussion of Fair's paper, Modigliani claimed: "with no oil problem the picture would have been a great deal different" (Fair 1978, 199). It was the major point of contention with Monetarist and New Classical economists. Lucas and Sargent did not mention the oil issue or supply shocks at all in their article. For them, the stagflation phenomenon resulted from changes in the structure of the economy. ${ }^{25} \mathrm{In}$ other words, the changes in individuals' behaviour modified the way economic variables used to vary. For the other side, the failure of macroeconometric models came from the absence of important variables that were not at play before the 1970 s. ${ }^{26}$ Klein summed up the opposition recently: “I believe the economy didn't change in structure; instead exogenous inputs changed a great deal within a largely unchanged structure" (Klein in Errouaki and Nell [2013, preface]). He already developed the same point in the 1970s, in a letter to G. Worswick (National Institute of Economic and Social Research): “

I will say that recent experience in the U.S. with double-digit inflation, the present recession, and economic fluctuations generally do not indicate to me that basic structures have changed. Models need periodic updating, but it has not been a case of parametric shift or changing specification; it is more a matter of changing inputs - initial conditions and exogenous variables - together with some large

\footnotetext{
${ }^{25}$ In his interview with Snowdon and Vane $(1998,152)$, Lucas later claimed that "the direct effect of the OPEC shock was minor".

${ }^{26}$ See Goutsmedt, Pinzon-Fuchs et al. (2019) for other examples of Keynesians defending supply-shocks explanation of the stagflation in the 1970s.
} 
random disturbances - oil embargo, cartel pricing of oil, strikes, etc. (LKP26,

Folder “Correspondence W, 1975”, 4/02/1975).

Even if macroeconomists debated the spread of the forecast errors of the 1970s and how fast they corrected them, it remains that the models had some difficulties to follow the disturbances of the 1970s. Nevertheless, it does not mean that one can easily spot the causes of these errors. Interestingly, Duo Qin $(2013,120)$ stresses this very same idea, when discussing the role of the Lucas Critique in the evolution of econometrics:

It is interesting to note that the argument no longer associates time-varying parameter estimates with the omitted-variable problem. Instead, time-varying parameters are regarded as the structural representation of the changing behavior of agents as they adapt to changing economic reality, a position which bears close similarity to Lucas's (1976) critique.

One can conceive the variation of a behavioural parameter (and so forecast errors) either as resulting from the omission of some factors (like expectations or supply shocks) or as being the consequence of individuals reacting to variations of the economic environment (like changes in economic policy). The second case implies substantial transformations of modelling practices because it requires deducing behavioural parameters more strictly from microeconomic decisions. If one favours the first option to explain the stagflation, even if one acknowledges some veracity in the second option, one has some rationale for being reluctant against a revolution in modelling strategy.

Consequently, I claim that we cannot disentangle the stagflation issue from the methodological debate of the 1970s. At the time, the radical transformations Lucas and Sargent advocated relied on a particular interpretation of the causes of Keynesian 
models forecast errors and so on a particular explanation of stagflation. ${ }^{27}$ Above all, it is also the interpretation of these errors and the explanation of stagflation that supported the research program of the defenders of large-scale macroeconometric models.

\section{Not giving up: the "aggregation program" in the $1970 \mathrm{~s}$}

The aggregation program described by Hoover (2012) had Klein as its best representative. It relied on a dialogue between microeconomics and macroeconomics and not just absorption of the latter by the former. The dialogue was not only of "logical implication", because the "commitment to microeconomics is not merely theoretical (...) but empirical"' (Hoover 2012, 44).

Erich Pinzón-Fuchs (2017) explained that the goal of Klein was to represent the whole economic system in all its completeness, and so to deal with various phenomena. Such a goal went through the building of separate parts of the economic system. Within this project, the general macroeconometric model unified several building blocks, each one touching on a particular portion of the real economy. The natural extension of the aggregation program hinged upon the development of new building blocks and the disaggregation of existing equations.

${ }^{27}$ That the issue of the causes of models forecast errors appeared linked to Lucas and Sargent's methodological point was obvious in Ando's (1981) article presented in Ann Arbor in October 1978. He explained how the reading of "After Keynesian Macroeconomics" pushed him to change totally the content of his presentation and aimed at criticizing Lucas and Sargent's article. A long part of this criticism (the second section of the article) focused on the issue of macroeconometric models performance and the interpretations of this performance. 
This program of research remains active in the 1970s. Many of its manifestations were observable during the Martha's Vineyard conference, and Klein participated to several conferences and wrote many articles in the late 1970s to defend the program. Most of the time, he did not address directly the issues raised by New Classical economists and seemed much more worried about the competition with small and a-theoretical models - that were renewing at the time with Christopher Sims's work. Nevertheless, the Martha's Vineyard conference, as well as Klein's writing in this period, witnessed the appearance of a clear definition of this program of research and its agenda.

The first striking fact is Klein's recurrent definition of large-scale macroeconometric models, which bore similarities with Lucas and Sargent's business cycle models. In a conference held in Pisa in December 1980, he presented macroeconometric models as stemming from a "Walrasian spirit" and as a "nonlinear", "stochastic", and "dynamic" "system of simultaneous equations" (Klein 1982a, 23). With his co-authors, in a conference occurring in October 1978 in Ann Arbor, he underlined that most of the models are "market clearing" but "possibly with time lags", and "parameter values are restricted wherever possible in accord with economic theory to achieve a parsimonious parameterization and stability of the dynamic system" (Howrey et al. 1981, 53).

Klein (1982a, 32) seemed attached to what he called a "Walrasian ideal." The "general equilibrium analysis" (Klein et Fromm 1981, 370) constituted the fundamental justification for the scale of models. Klein and other advocates of the aggregation program insisted on the necessity for the models to be large. Macroeconomists should be able to use their models to describe a large set of economic phenomena comprehensively, which means to be able to account for all the mechanisms at work. 
However, this is not important just for describing and explaining economic phenomena, but also for policy analysis. Klein $(1977,774)$ explained that his "preferred research strategy is to build large general purpose models, maintained in a tuned-up status, on line, at all times and capable of accommodating a wide variety of policy issues". Targeting policy analysis implied to integrate a large number of details. Public policy is not concerned with overall public spending and level of taxation, but with "excise tax rates", "investment tax credits, social insurance rates", "regulation of oil prices," “interest rates ceilings," etc. (669). For Klein that was the only way to understand the channels of transmission of shocks or particular policies.

In the Ann Arbor Conference, three months after the one in Martha's Vineyard, Klein and Gary Fromm were in charge of defending the size of large-scale models. Considering how uneasy it could be to add quickly and efficiently "new sectors", the econometrician had to build large model in advance to be "potentially ready to analyze the effect of recent crop harvests, of a longshore man's strike, of the oil shortage, of new pieces of tax legislation or federal spending shortfalls" (Klein et Fromm 1981, 37071). This justification for large size, which came mainly for external demand, also strengthened the case for large-scale models in the 1970s. The problems of "agricultural failures" and "the energy crisis" called for an analysis "within a general equilibrium context and not within a partial system or small macro system context”. In other words, for Klein and Fromm, the stagflation constituted an argument to support macroeconometric models rather than to abandon them.

A clear research program stemmed from this defence of large-scale models. New building blocks should be integrated in existing models. As the president of the American Economic Association, Klein gave an address in December 1977, soberly 
called "the Supply Side" (Klein 1978b). He exposed the path he had in mind for further research in macroeconomics:

Yet the economic problems of today seem to be intractable when studied through the medium of simplified macro models. The new system should combine the Keynesian model of final demand and income determination with the Leontief model of interindustrial flows. This is the motivation for my focusing attention on the supply side of the economy. (Klein 1978b, 1)

Klein advocated the modelling of an energy sector to understand the role of supply shocks. This constituted a major task for the Wharton model in these years. A way to increase the number of details in the model, without compromising its tractability, relied on building "satellite models". In a conference in July 1978, he described this use of satellite models. He contributed to building the Wharton Agricultural Model, which was a large forecasting model. This model interacted with the Wharton Model of the US economy. Iterative steps between the two models aimed at forecasting and analysing the effect of agricultural events on the whole U.S. economy (Klein 1979, 320-21).

The LINK model that Klein developed with a large team of econometricians since the late 1960s also constituted a perfect example of such a research program. The goal was to build a tractable system, which linked national models to endogenise usually exogenous variables in national models, and so to use the results of the simulations to improve forecasts and policy analysis in national models.

Even if there was a long way ahead, according to Klein, to improve this model after the disturbances of the 1970s, he considered that they were already helpful. As Ando (1981) did in the same conference, Klein and Fromm (1981) endeavoured to defend the assessment of large-scale models in the early 1970s. They showed that the Wharton model predicted "the policy induced slowdown of 1973 combined with the oil embargo would produce a recession" (377). The model forecasted this in November 
1973. The authors underlined that large models, thanks to input-output analysis, allowed understanding how the oil embargo could have a significant effect on the whole economy. $^{28}$

In the late 1970s, the advocates of large-scale models did not give up in front of attacks by Monetarists, New Classical economists and promoters of a-theoretical models. They defended a program of research with clear objectives to fix the problems encountered in the early 1970s, but above all to explain an unprecedented situation, the stagflation, and to stay able to help policymaking.

Most of the histories of the period acknowledged the emergence of the New Classical program but failed to spot and characterise the aggregation program. Nonetheless, the end of the 1970s witnessed the struggle between two research programs for macroeconometric modelling. Thus, what distinguished the two programs at the time? Cherrier and Backhouse $(2018,5)$ have a point when they highlight that large scale models displayed a certain "messiness", but that econometricians "endorsed it". For Lucas and Sargent, it was "a mess in the sense that the models did not follow rigorously from a consistent theory" (4). Even if it could have constituted a weakness in their modelling practice, advocates of these models acknowledged it. They had different "epistemic commitments" (4) regarding the relationship between economic theory, econometric models and data.

Following the distinction developed by Hoover (1994), we can summarise the opposition as bearing on the degree of apriorism defended by modellers. The two

\footnotetext{
${ }^{28}$ They claimed that such a forecast was impossible with simple "rules-of-thumb" that calculate the ratio of oil sector in the total GNP.
} 
groups agree that macroeconometric models should be identified with the help of economic theory, meaning a Walrasian approach with optimisation by economic agents. However, what opposed them is the degree of constraint imposed by economic theory. Rational expectations implied a large rebuilding of macroeconometric models.

Klein supported more flexibility in model building. In Ann Arbor, he claimed with his co-authors that "micro-economic formulations can not always be applied uncritically on the macro level. (...) It may not be sensible to impose the restrictions implicit in a neat mathematical solution to a micro-economic problem on the macroeconomic relationship" (Howrey et al. 1981, 27). ${ }^{29}$ This issue closely linked to the problem of aggregation. It implied that economists studied how the aggregation of "hypothesized micro-relationships can be expected to manifest themselves in macroeconomic aggregates". The problem for Klein was that optimisation problems "rarely apply to groups or aggregates of economic agents", what implies "[aggregating] over all decision units and sometimes over types of goods" (Klein 1982a, 30). As economic theory "does not have much to say on aggregation", economists need to build bridges between micro- and macro-relationships. For Klein, this led to the use of new data describing the distribution of aggregate economic variables (like variance or concentration measures). The aggregation programme relied on a dialogue between microeconomic and macroeconomic theory, as well as between microeconomic and macroeconomic data.

\footnotetext{
${ }^{29}$ It is worth noting that the authors nevertheless stated that "the models of today use much more micro-economic theory (...) than was the case thirty years ago or even ten years ago" and that "micro-economic theory is to have an even more important impact on macro-economic model formulation" (Howrey et al. 1981, 27). Here again, we observe that the question of microfoundations at the time is more complex that what a standard narrative in macroeconomics relates.
} 
Defending a different but consistent research program, advocates of large-scale macroeconometric models could not accept the radical arguments of New Classical economists that condemned these models. They had their own agenda, motivated by the stagflation context, and they defended another relationship between macro- and microlevels. During the FRB of Boston conference, many acknowledged that New Classical ideas could be useful, and seemed to regard rational expectations as an interesting modelling tool. It could contribute to elaborate the modelling of expectations in largescale models that was recognised as a weakness (see Modigliani's quotation above). Nevertheless, they rejected the sharp break promoted by Lucas and Sargent.

Despite significant differences in terms of methodology and epistemic commitment, some paths of convergence remained possible between New Classical economists and advocates of large-scale models. However, in 1978, due to aggressive rhetoric in each camp, but also due to crucial divergences about stagflation and economic policy, the ground was not fertile for such a convergence.

\section{Concluding remarks}

If Wren-Lewis was seduced by Lucas and Sargent's article, I wonder how much he would reject the words of Klein and other advocates of large-scale models in the same period. Indeed, the gap on specific issues between the two was not as large as one can sometimes think. As well, the abiding points of disagreement remain significant issues today. ${ }^{30}$ Lucas and Sargent's article charmed many macroeconomists at the time.

\footnotetext{
${ }^{30}$ Recently, the European Central Bank decided to abandon its DSGE model and to build a new model in the spirit of the FRB/US, justifying this move by the rigidity imposed by the
} 
However, it should not lead us to forget the other camp and refuse to study it. This collective memory lapse could be the consequence of Lucas and Sargent successfully fulfilling their initial goal: by writing a "frankly rhetorical piece" with talent, they succeeded in catching the spotlight of historical credit and relegating alternative approaches in the dark.

1978 constituted a crossroad in macroeconomics with two confronting research programs. The debate between these two programs never really took place, partly because of the rhetorical style of both groups - to Lucas and Sargent's offensive tone answered Solow's touches of sarcasm. 1978 was a dialogue of the deaf. The New Classical ideas gained more and more popularity in academia, and large scale models appeared outmoded. In the same time, these models continued to serve and to be developed in policymaking institutions until the arrival of DSGE models in the second mid of the 1990s - and some survived these newcomers.

Part of this mutual impermeability resulted from a general entanglement between different issues. The methodological struggle overlapped with debating interpretations of stagflation, while public and private demand of expertise put pressure on modellers. The debates during Martha's Vineyard conference and more generally during the period were not abstract debates in the ivory tower of academia, and it necessarily complicated the reading we have of the period.

History helps us to keep in mind that debates are often complex and never solved easily, and it underlines the entanglement between different levels of economists' practices. By enlarging and refining the picture we draw of

DSGE discipline (Constancio 2017). As for the academic field, Wren-Lewis himself (2018) questioned the ascendency of microeconomic theory on macroeconomic modelling. 
macroeconomics history, we can hope to contribute to the current debates on the future of macroeconomics and the use of macroeconometric models, debates that bear an indubitable similarity with the 1970 s one.

\section{References}

\section{Archives}

RLP: Robert E. Lucas Papers, 1960-2011 and undated. David M. Rubenstein Rare Book \& Manuscript Library, Duke University, Durham (NC).

RLP3 : Box 3 ; RLP19: Box 19.

RSP: Robert M. Solow Papers, David M. Rubenstein Rare Book \& Manuscript Library, Duke University.

RSP5: Box 5; RSP10: Box 10.

LKP: Lawrence Klein Papers, David M. Rubenstein Rare Book \& Manuscript Library, Duke University.

LKP26: Box 26

\section{Published References}

Acosta, Juan, et Beatrice Cherrier. 2018. « The transformation of economic analysis at the Federal Reserve during the 1960s ».

Acosta, Juan, et Erich Pinzón-Fuchs. Forthcoming. « Macroeconometric Modeling and the SSRC's Committee on Economic Stability, 1959-1963 ». Oeconomia, $\mathrm{n}^{\circ}$ 2018-08.

Ando, Albert. 1981. «On a theoretical and Empirical Basis of Macroeconometric Models ». In Large-Scale Macro-Econometric Models, édité par Jan Kmenta et James Bernard Ramsey, 329-68. Contributions to Economic Analysis. Amsterdam; New York ; Oxford: North Holland.

Arrow, Kenneth J. 1964. «The Role of Securities in the Optimal Allocation of Riskbearing ». The Review of Economic Studies 31 (2): 91-96. 
Arrow, Kenneth J, et Gerard Debreu. 1954. «Existence of an equilibrium for a competitive economy ». Econometrica: Journal of the Econometric Society, 265-290.

Barro, Robert J. 1977. «Unanticipated Money Growth and Unemployment in the United States ». The American Economic Review 67 (2): 101-15.

Blinder, Alan S., et Jeremy B. Rudd. 2013. « The supply-shock explanation of the Great Stagflation revisited ». In The Great Inflation: The Rebirth of Modern Central Banking, 119-175. University of Chicago Press. http://www.nber.org/chapters/c9160.

Chappell, Henry W., Rob Roy McGregor, et Todd A. Vermilyea. 2005. Committee Decisions on Monetary Policy: Evidence from Historical Records of the Federal Open Market Committee. Cambridge: MIT Press.

Cherrier, Beatrice, et Roger Backhouse. 2018. «The ordinary business of macroeconometric modeling: working on the Fed-MIT-Penn model (19641974) », octobre. https://doi.org/10.31235/osf.io/39xkz.

Constancio, Vitor. 2017. « Developing models for policy analysis in central banks ». In Opening Speech at the Annual Research Conference of the European Central Bank. Frankfurt.

De Vroey, Michel. 2016. A History of Macroeconomics from Keynes to Lucas and Beyond. Cambridge: Cambridge University Press.

Debreu, Gerard. 1959. Theory of Value: An Axiomatic Analysis of Economic Equilibrium. Yale University Press.

DiCecio, Riccardo, et Edward Nelson. 2013. « The great inflation in the United States and the United Kingdom: reconciling policy decisions and data outcomes ». In The Great Inflation: The Rebirth of Modern Central Banking, 393-438. University of Chicago Press. http://www.nber.org/chapters/c9172.

Errouaki, Karim, et Edward J. Nell. 2013. Rational Econometric Man: Transforming Structural Econometrics by Edward J. Nell. Cheltenham, UK ; Northampton, MA: Edward Elgar Publishing.

Fair, Ray C. 1978. «Inflation and Unemployment in a Macroeconometric Model ». In After the Phillips Curve: Persistence of High Inflation and High Unemployment, 164-200. Boston: Federal Reserve Bank of Boston. 
Fair, Ray C., et Dwight M. Jaffee. 1972. « Methods of Estimation for Markets in Disequilibrium ». Econometrica 40 (3): 497-514. https://doi.org/10.2307/1913181.

FRBB (Federal Reserve Bank of Boston). 1978. After the Phillips Curve: Persistence of High Inflation and High Unemployment. Conference series 19. Boston Mass.: Federal Reserve Bank of Boston. https://www.bostonfed.org/news-andevents/events/economic-research-conference-series/after-the-phillips-curvepersistence-of-high-inflation-and-high-unemployment.aspx.

Friedman, Milton. 1968. « The Role of Monetary Policy ». The American Economic Review 58 (1): 1-17.

Goodfriend, Marvin, et Robert G. King. 2013. « The great inflation drift ». In The Great Inflation: The Rebirth of Modern Central Banking, 181-209. University of Chicago Press. http://www.nber.org/chapters/c9168.

Goutsmedt, Aurélien. 2018. « Thomas Sargent face à Robert Lucas: une autre ambition pour la Nouvelle Economie Classique ». Oeconomia 8 (2).

Goutsmedt, Aurélien, Danielle Guizzo, et Francesco Sergi. 2019. «An agenda without a plan: Robert E Lucas's trajectory through the public debate ». Oeconomia Forthcoming.

Goutsmedt, Aurélien, Erich Pinzón-Fuchs, Matthieu Renault, et Francesco Sergi. 2019. « Reacting to the Lucas Critique: The Keynesians’ Pragmatic Replies ». History of Political Economy 51 (3).

Hall, Robert E. 1996. « Robert Lucas, Recipient of the 1995 Nobel Memorial Prize in Economics ». The Scandinavian Journal of Economics 98 (1): 33-48. https://doi.org/10.2307/3440578.

Hickman, Bert G. 1991. « Projetct LINK and multi-country modelling ». In A History of Macroeconometric Model-Building, par Ronald G. Bodkin, Lawrence R. Klein, et Kanta Marwah, 482-506. Aldershot (GB) Brookfield (Vt.): Edward Elgar Publishing.

Hoover, Kevin D., éd. 1988. The New Classical Macroeconomics. 3 vol. The International Library of Critical Writings in Economics 19. Aldershot (GB) Brookfield (Vt.): E. Elgar. 
- 1994. «Econometrics as observation: the Lucas critique and the nature of econometric inference ». Journal of Economic Methodology 1 (1): 65-80. https://doi.org/10.1080/13501789400000006.

- 2012. «Microfoundational programs ». In Microfoundations Reconsidered, édité par Pedro Garcia Duarte et Gilberto Tadeu Lima, 19-61. Cheltenham, UK; Northampton, MA, USA: Edward Elgar.

Howrey, E. Philip, Lawrence R. Klein, Michael D. McCarthy, et George R. Schink. 1981. «The practise of Macroeconometric Model Building and Its Rationale ». In Large-Scale Macro-Econometric Models, 19-58. Contributions to Economic Analysis. Amsterdam: North-Holland.

Klamer, Arjo. 1984. Conversations with Economists: New Classical Economists and Opponents Speak out on the Current Controversy in Macroeconomics. Rowman $\&$ Allanheld.

Klein, Lawrence R. 1977. «Economic policy formation through the medium of econometric models ». In Frontiers of Quantitative Economics, par Michael D. Intriligator, 3:765-82. Amsterdam: North Holland.

_ 1978a. «Disturbances to the International Economy ». In After the Phillips Curve: Persistence of High Inflation and High Unemployment, 84-103. Boston: Federal Reserve Bank of Boston.

_. 1978b. «The Supply Side ». The American Economic Review 68 (1): 1-7.

- 1979. «Use of econometric models in the policy process ». In Economic Modelling: Current Issues and Problems in Macroeconomic Modelling in the UK and the US, édité par Paul Ormerod, 309-329.

. 1982a. «Economic Theoretic Restrictions in Econometrics ». In Evaluatig the Reliability of Macro-economic Models, par Gregory C. Chow et Paolo Corsi, 23-42. New York: John Wiley \& Sons.

-1982b. «The neoclassical tradition of Keynesian economics and the generalized model ». In Samuelson and Neoclassical Economics, édité par George R. Feiwel. Boston Mass.: Klerwer-Nijhoff.

Klein, Lawrence R., et Gary Fromm. 1981. « Scale of Macro-Econometric Models and Accuracy of Forecasting ». In Large-Scale Macro-Econometric Models, 19-58. Contributions to Economic Analysis. Amsterdam: North-Holland. 
Klein, Lawrence R, et Arthur S. Goldberger. 1955. «Econometric model of the United States, 1929-1952».

Krugman, Paul. 2014. «Stagflation and the Fall of Macroeconomics ». New York Times Paul Krugman Blog (blog). 28 juin 2014.

https://krugman.blogs.nytimes.com/2014/06/28/stagflation-and-the-fall-ofmacroeconomics/.

Kydland, Finn E., et Edward C. Prescott. 1982. « Time to build and aggregate fluctuations ». Econometrica: Journal of the Econometric Society 50 (6): 13451370.

Levin, Andrew, et John B. Taylor. 2013. «Falling Behind the curve: A positive Analysis of Stop-Start Monetary Policies and the Great Inflation ». In The Great Inflation: The Rebirth of Modern Central Banking, 217.

https://books.google.com/books?hl=en\&lr=\&id=D6ABCwix0hkC\&oi=fnd\&pg= PA217\&dq $=\% 22$ since + the + founding + of + the + Federal + Reserve + -Many + analyst s+and $\% 22+\% 22$ Levin+is+an+economist+at+and+special+adviser+to+the+Boar $\mathrm{d}+\mathrm{of}+$ Governors+of+the\%22+\&ots=OMEkImORG8\&sig=yW2aSdbWvZ1Dixk kYntwUReNVOs.

Lucas, Robert E. 1976. «Econometric policy evaluation: A critique ». CarnegieRochester Conference Series on Public Policy 1: 19-46. https://doi.org/10.1016/S0167-2231(76)80003-6.

Lucas, Robert E, Jr. 1972. «Expectations and the neutrality of money ». Journal of Economic Theory 4 (2): 103-24. https://doi.org/10.1016/0022-0531(72)90142-1.

Lucas, Robert E, Jr., et Thomas J. Sargent. 1978. « After Keynesian Macroeconomics ». In After the Phillips Curve: the Persistence of High Inflation and High Unemployment, 49-83. Boston: Federal Reserve Bank of Boston.

Mankiw, N. Gregory. 1990. «A Quick Refresher Course in Macroeconomics ». Journal of Economic Literature 28 (4): 1645-60.

Meltzer, Allan Harold. 2010. A History of the Federal Reserve Book 2: 1970-1986. Vol. 2. 2 vol. A History of the Federal Reserve. Chicago: The university of Chicago press.

Morris, Frank E. 1978. «Opening Remarks ». In After the Phillips Curve: Persistence of High Inflation and High Unemployment, 7-9. Federal Reserve Bank of Boston. 
Muench, Thomas, Arthur Rolnick, et Neil Wallace. 1974. «Tests for Structural Change and Prediction Intervals for the Reduced Forms of Two Structural Models of the US: The FRB-MIT and Michigan Quarterly Models ». In Annals of Economic and Social Measurement, Volume 3, number 3, 491-519. NBER. http://www.nber.org/chapters/c10174.pdf.

Pinzón-Fuchs, Erich. 2017. «Economics as a “Tooled” Discipline: Lawrence R. Klein and the Making of Macroeconometric Modeling, 1939-1959 ». Paris: Université Paris I Panthéon-Sorbonne.

Poole, William. 1978. «Summary and Evaluation ». In After the Phillips Curve: Persistence of High Inflation and High Unemployment, 210-15. Boston: Federal Reserve Bank of Boston.

Qin, Duo. 2013. A History of Econometrics: The Reformation from the 1970s. Oxford: Oxford University Press.

Romer, Christina D. 2005. «Commentary on "Origins of the Great inflation" by Meltzer ». Federal Reserve Bank of St. Louis Review 87 (2): 177-86.

Romer, Paul M. 2015. « Solow's Choice ». Paulromer.net. 2015. https://paulromer.net/solows-choice/.

Sargent, Thomas J. 2013. Rational Expectations and Inflation. Princeton University Press.

Shimer, Robert. 2009. « Convergence in macroeconomics: The labor wedge ». American Economic Journal: Macroeconomics 1 (1): 280-97.

Snowdon, Brian, et Howard R. Vane. 1998. «Transforming Macroeconomics: An Interview with Robert E. Lucas Jr. » Journal of Economic Methodology 5 (1): 115-46. https://doi.org/10.1080/13501789800000005.

_ 2005. Modern Macroeconomics: Its Origins, Development and Current State. 1 vol. Cheltenham (GB): E. Elgar.

Solow, Robert. 1978. « Summary and Evaluation ». In After the Phillips Curve: Persistence of High Inflation and High Unemployment, 203-9. Boston: Federal Reserve Bank of Boston.

Wren-Lewis, Simon. 2014a. «Understanding the New Classical revolution ». Mainly Macro (blog). 28 juin 2014. https://mainlymacro.blogspot.com/2014/06/understanding-new-classicalrevolution.html. 
_. 2014b. «Rereading Lucas and Sargent 1979 ». Mainly Macro (blog). 11 juillet 2014. https://mainlymacro.blogspot.com/2014/07/rereading-lucas-and-sargent1979.html.

. 2018. «Ending the Microfoundations Hegemony ». Oxford Review of

Economic Policy 34 (1-2): 55-69. https://doi.org/10.1093/oxrep/grx054. 